\begin{tabular}{|l|c|c|c|r|}
\hline $\begin{array}{l}\text { Cuadernos de Investigación Geográfica } \\
\text { Geographical Research Letters }\end{array}$ & 2017 & N $^{\circ} 43(1)$ & pp. 255-268 & $\begin{array}{r}\text { ISSN 0211-6820 } \\
\text { eISSN 1697-9540 }\end{array}$ \\
\hline
\end{tabular}

\title{
PRECIPITATION TRENDS AND A DAILY PRECIPITATION CONCENTRATION INDEX FOR THE MID-EASTERN ATLANTIC (CANARY ISLANDS, SPAIN)
}

\author{
P. MÁYER ${ }^{1 *}$, M.V. MARZOL ${ }^{2}$,J.M. PARREÑO ${ }^{3}$ \\ ${ }^{1}$ Grupo de Geografía Física y Medio Ambiente, Instituto de Oceanografía y Cambio Global (IOCAG), \\ Universidad de Las Palmas de Gran Canaria, C/ Pérez del Toro, 1, 35003 Las Palmas de Gran Canaria. \\ ${ }^{2}$ Dpto. de Geografía e Historia, Universidad de La Laguna, Campus de Guajara, 38070 La Laguna. \\ ${ }^{3}$ Grupo Sociedades y Espacios Atlánticos, Departamento de Geografía, Universidad de Las Palmas de \\ Gran Canaria, C/Pérez del Toro, 1, 35003 Las Palmas de Gran Canaria.
}

\begin{abstract}
This paper pursues two objectives: first, to determine the trends of seasonal and annual precipitation in the Canary Islands and, second, to identify trends in the daily precipitation concentration index (CI). For the first objective, we used data from 1970-2013 of 23 rainfall stations located on different islands, after verifying the homogeneity of their series. For the second, the sample was reduced to eleven series since deficiencies in data records of less than $1 \mathrm{~mm}$ of daily precipitation were appreciated. We used the nonparametric Mann-Kendall test to determine whether the series showed linear trends in annual and seasonal precipitation and in the values of CI. The seasonal results showed negative trends in spring and winter in almost all the time series considered, especially in the north of Gran Canaria and Tenerife. Conversely, $78 \%$ of the series in autumn recorded an increase in the precipitation. The annual balance indicated a decline of rainfall in most of the locations, because of the high concentration of precipitation in winter. Finally, most of the time series exhibited a trend toward a greater concentration of daily rainfall, in particular those series located in areas where the main towns are settled, which is an important issue to consider because of severe flooding and other geomorphological processes.
\end{abstract}

Tendencias de la precipitación y del índice de concentración de la precipitación diaria en el Atlántico Medio-Oriental (Islas Canarias, España)

RESUMEN. Este trabajo persigue dos objetivos: en primer lugar, determinar las tendencias estacionales y anuales de la precipitación en las Islas Canarias $y$, en segundo lugar, identificar las tendencias del índice de concentración de la precipitación diaria (CI). Se usaron 23 estaciones pluviométricas de diferentes islas para el periodo 1970-2013, una vez verificada la homogeneidad de sus series, para el primer objetivo; mientras que para el segundo la muestra se redujo a once series, ya que se observaron deficiencias en la toma de los datos inferiores 
a $1 \mathrm{~mm}$ de precipitación diaria. Se empleó el test no paramétrico de MannKendall para determinar qué estaciones muestran una tendencia lineal en la precipitación anual y estacional y en los valores del índice de concentración. Los resultados estacionales mostraron que en la primavera y el invierno predominan, en la mayor parte de las series, tendencias negativas de la precipitación especialmente en las vertientes septentrionales de Gran Canaria y Tenerife. Por el contrario, durante el otoño existían evidencias, en un $78 \%$ de las series, hacia un incremento de la precipitación. Debido a la fuerte concentración de las precipitaciones durante el invierno el balance anual era hacia una disminución de las lluvias en la mayor parte de las localidades. Finalmente, la mayoría de las series consideradas mostraron una tendencia hacia una mayor concentración de la precipitación, especialmente las localizadas en aquellas zonas en donde se ubican los principales núcleos de población, lo que es importante porque puede relacionarse con el incremento de posibles inundaciones y otros procesos geomorfológicos.

Key words: Canary Islands, daily precipitation concentration index (CI), MannKendall test, precipitation trend analysis.

Palabras clave: Islas Canarias, índice de concentración de la precipitación diaria, test de Mann-Kendall, análisis de tendencia de la precipitación.

Received: 16 September 2016 Accepted: 12 January 2017

* Corresponding author: Pablo Máyer, Grupo de Geografía Física y Medio Ambiente, Instituto de Oceanografía y Cambio Global (IOCAG), Universidad de Las Palmas de Gran Canaria, C/ Pérez del Toro, 1, 35003 Las Palmas de Gran Canaria, Spain. E-mail address: pablo.mayer@ulpgc.es

\section{Introduction}

The Canary archipelago consists of a group of seven islands and several islets in the mid-Eastern Atlantic between $27^{\circ} 37^{\prime} \mathrm{N}$ and $29^{\circ} 25^{\prime} \mathrm{N}$ and $13^{\circ} 20^{\prime} \mathrm{W}$ and $18^{\circ} 10^{\prime} \mathrm{W}$, occupying a total area of $7447 \mathrm{~km}^{2}$ (Fig. 1). The average annual rainfall ranges from 1500 $\mathrm{mm}$ in the northeast of the island of La Palma to less than $100 \mathrm{~mm}$ in the southern areas of Gran Canaria, Tenerife, Lanzarote and Fuerteventura. This considerable difference in the total annual rainfall for the different latitudinal locations of the islands is due to the passage of cloud fronts from the Atlantic and the combination of altitude and orientation of the relief with respect to cloud cover. This variability in rainfall creates a large range of conditions, from the wettest on the northern slopes of the higher islands to the driest on the southern slopes and almost all of the two easternmost islands (Marzol and Máyer, 2012). Rainfall is concentrated during the winter months, although sporadic equinoctial rains associated with the passage of the Atlantic fronts occur. The most common duration of rainfall episodes is one or two days, which produces a remarkable concentration and intensity of rain. High daily precipitation concentration index (CI) values range from 
0.7 in the east and south and 0.5 in the north. Moreover, $50 \%$ of the annual precipitation occurs during these events (Marzol et al., 2006). This high concentration of rain, often in episodes of high intensity, results in severe incision in the channels of ravines, causing severe flooding in major population centers (Máyer, 2011). For this reason, it is important to characterize the precipitation regime in these islands, not only from the hazard point of view but also because it is a resource on which its inhabitants depend largely.

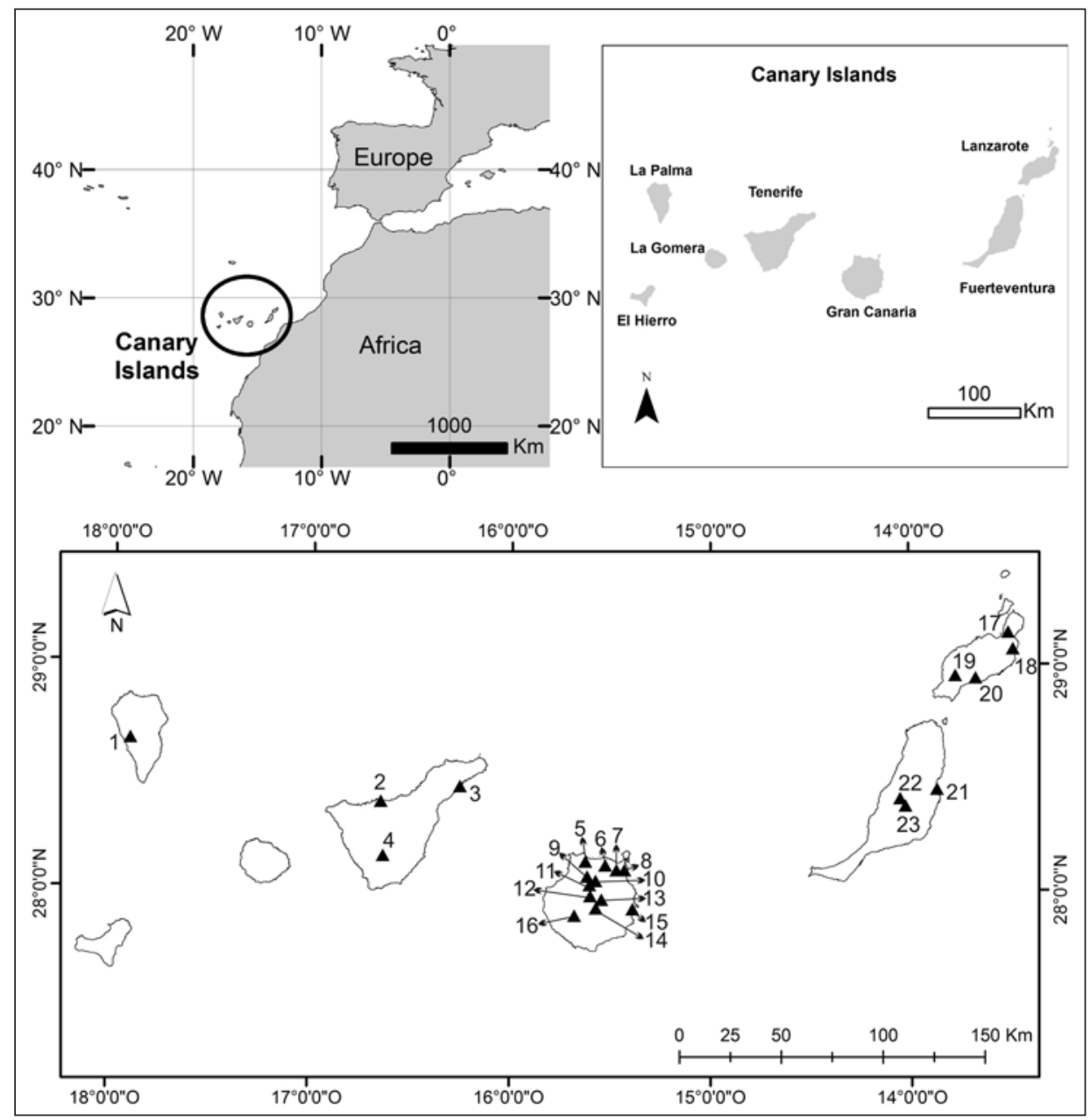

Figure 1. Locations of the stations used in this study.

Recent studies carried out in the mid-Eastern Atlantic, including the Azores, Madeira, Canary and Cape Verde archipelagos (Cropper and Hanna, 2014), show (i) a significant increase in precipitation in Cape Verde during the wet season (August, September and October), (ii) a positive trend in the total rainfall from 1981 to 2010 on some islands of 
the Azores, and (iii) no significant trends in the Canary and Madeira islands. Studies on the Canary Islands (García-Herrera et al., 2003; De Luque and Martín-Esquivel, 2011; Tarife et al., 2012; Sánchez-Benítez et al., 2016) show variable trends in precipitation with low statistical significance depending on the orientation of the slopes. However, greater concentrations of rainfall and an increasing number of extreme events have been observed (García-Herrera et al., 2003; Tarife et al. 2012). Therefore, it is essential to analyze trends in precipitation on islands (e.g., Canary Islands) where $25 \%$ of rainy days provides more than $70 \%$ of the annual rainfall (Marzol and Máyer, 2012). A confirmed trend of higher concentrations of precipitation would imply an increased risk of erosion, increased flooding, and increased frequency of geomorphic processes such as landslides. These hazards can have acute consequences on islands with marked slopes and where population concentrates near the coast and near the beds of ravines.

Precipitation trends statistically significant are difficult to obtain in this region of the Atlantic because the data show a great variability compared to other regions with more regular rainfall (Sánchez-Benítez et al., 2016). Therefore, the possible precipitation trends in the Atlantic region must be analyzed at different levels and scales, taking the seasons into account and considering the orientation of the slopes on each island (García Herrera et al., 2001). To this end, the objectives of this study are as follows: (i) to determine the trends of seasonal and annual precipitation in the Canary Islands and their statistical significance, and (ii) to establish possible trends in daily precipitation through the application of the CI proposed by Martin-Vide (2004).

Based on preliminary studies of the characteristics of the rainfall in this region of the Atlantic and on the geographical peculiarities of the Canary Islands (García Herrera et al., 2001; Máyer and Marzol, 2012), we hypothesized a negative trend in precipitation that could be increased or even reversed by geographical factors. When rainfall decreases, the trend is toward a greater precipitation concentration (García-Herrera et al., 2003; Tarife et al., 2012). Therefore, we also hypothesized a current scenario of increasing daily precipitation concentration.

This paper is organized as follows. First, the daily precipitation data and the different tests used to determine their homogeneity are presented. Then, the methodology is described, focusing on the calculation of the CI values and the nonparametric Mann-Kendall test. Third, we present the results using the following sequence: (i) test of homogeneity, (ii) seasonal and annual trends in the different precipitation time series, and (iii) the CI values obtained as well as the trends of those series that were considered homogeneous. We then proceed to the discussion of the results and, finally, to the conclusions.

\section{Dataset}

The Canary Islands have a wide network of rainfall observatories, particularly in the eastern islands (Gran Canaria, Lanzarote and Fuerteventura), as a result of the efforts made in the mid-twentieth century by the Las Palmas Hydraulic Service, primarily in conjunction with the building of large dams, especially in Gran Canaria. These stations are managed by different agencies (State Meteorological Agency -AEMET-), Water Services and Water 
Island Councils). In this study we used only 23 of the 500 stations, all of them from the AEMET (Fig. 1). We had to remove data from many of the stations because of discontinuity in the time series and changes in the measuring instruments and/or their locations. Alltime series begun between 1930 and 1950, although the lack of continuity in some cases (especially between 1930 and 1970) recommended the use of a common analysis period between 1970 and 2013. The temporal resolution is daily, and the absence of data in the selected time series is negligible (between one and six months maximum). Missing data were simulated via a lineal regression analysis with the nearest stations with Pearson's $r>0.90$.

Table 1 shows the main features of the selected time series, highlighting large differences in the mean values and the significant contrasts in the values of the coefficients of variation. This indicates, among other things, a greater regularity of precipitation over northern slopes than over southern slopes.

Table 1. Main features of the time series considered in this study.

\begin{tabular}{|c|c|c|c|c|c|}
\hline CD & Name & Long (W)/Lat (N) & $\begin{array}{c}\text { Elevation } \\
\text { (m.a.s.l.) }\end{array}$ & $\begin{array}{l}\text { Mean annual } \\
\text { rainfall } \\
(1970-2013) \\
(\mathbf{m m})\end{array}$ & $\begin{array}{l}\text { CV } \\
(\%)\end{array}$ \\
\hline 1 & Llanos de Aridane & $17^{\circ} 54^{\prime} 37^{\prime \prime} / 28^{\circ} 39^{\prime} 32^{\prime \prime}$ & 410 & 383.5 & 41.3 \\
\hline 2 & San Juan de la Rambla & $16^{\circ} 39^{\prime} 02^{\prime \prime} / 28^{\circ} 23^{\prime} 38^{\prime}$ & 106 & 310.8 & 28.6 \\
\hline 3 & Santa Cruz de Tenerife & $16^{\circ} 15^{\prime} 19^{\prime \prime} / 28^{\circ} 27^{\prime} 47^{\prime}$ & 31 & 225.8 & 33.6 \\
\hline 4 & Vilaflor & $16^{\circ} 38^{\prime} 12^{\prime \prime} / 28^{\circ} 09^{\prime} 16^{\prime}$ & 1435 & 363.3 & 53.7 \\
\hline 5 & Presa de Jiménez & $15^{\circ} 37^{\prime} 30^{\prime \prime} / 28^{\circ} 08^{\prime} 00^{\prime \prime}$ & 240 & 242.1 & 31.5 \\
\hline 6 & Arucas & $15^{\circ} 31^{\prime} 30^{\prime \prime} / 28^{\circ} 07^{\prime} 00^{\prime}$ & 250 & 260.1 & 34.4 \\
\hline 7 & Tamaraceite & $15^{\circ} 28^{\prime} 10^{\prime \prime} / 28^{\circ} 05^{\prime} 45^{\prime \prime}$ & 200 & 236.6 & 37.6 \\
\hline 8 & Mayorazgo & $15^{\circ} 25^{\prime} 45^{\prime \prime} / 28^{\circ} 05^{\prime} 45^{\prime \prime}$ & 60 & 177.2 & 41.0 \\
\hline 9 & Lomo Majadilla & $15^{\circ} 36^{\prime} 57^{\prime \prime} / 28^{\circ} 04^{\prime} 00^{\prime \prime}$ & 980 & 599.1 & 27.5 \\
\hline 10 & Valleseco & $15^{\circ} 34^{\prime} 25^{\prime \prime} / 28^{\circ} 02^{\prime} 50^{\prime \prime}$ & 980 & 700.2 & 26.6 \\
\hline 11 & Retamilla & $15^{\circ} 36^{\prime} 12^{\prime \prime} / 28^{\circ} 01^{\prime} 44^{\prime \prime}$ & 1400 & 792.0 & 30.4 \\
\hline 12 & Culata de Tejeda & $15^{\circ} 36^{\prime} 01^{\prime \prime} / 27^{\circ} 58^{\prime} 50^{\prime \prime}$ & 1180 & 474.5 & 45.0 \\
\hline 13 & Cuevas Blancas & $15^{\circ} 32^{\prime} 40^{\prime \prime} / 27^{\circ} 57^{\prime} 50^{\prime \prime}$ & 1680 & 668.8 & 39.7 \\
\hline 14 & San Bartolomé de Tirajana & $15^{\circ} 34^{\prime} 20^{\prime \prime} / 27^{\circ} 55^{\prime} 33^{\prime \prime}$ & 880 & 364.3 & 60.2 \\
\hline 15 & Gando airport & $15^{\circ} 23^{\prime} 22^{\prime \prime} / 27^{\circ} 55^{\prime} 21^{\prime \prime}$ & 24 & 137.5 & 46.3 \\
\hline 16 & Barranquillo Andrés-Mogán & $15^{\circ} 40^{\prime} 45^{\prime \prime} / 27^{\circ} 53^{\prime} 35^{\prime \prime}$ & 715 & 299.3 & 49.4 \\
\hline 17 & Haría & $13^{\circ} 29^{\prime} 58^{\prime \prime} / 29^{\circ} 08^{\prime} 42^{\prime \prime}$ & 270 & 187.9 & 41.0 \\
\hline 18 & Teguise-Guatiza & $13^{\circ} 28^{\prime} 36^{\prime \prime} / 29^{\circ} 04^{\prime} 26^{\prime \prime}$ & 110 & 135.4 & 45.6 \\
\hline 19 & Yaiza & $13^{\circ} 46^{\prime} 07^{\prime \prime} / 28^{\circ} 57^{\prime} 18^{\prime \prime}$ & 150 & 151.2 & 41.8 \\
\hline 20 & Tías-Mácher & $13^{\circ} 41^{\prime} 59^{\prime \prime} / 28^{\circ} 56^{\prime} 44^{\prime \prime}$ & 160 & 151.7 & 41.4 \\
\hline 21 & Fuerteventura airport & $13^{\circ} 51^{\prime} 55^{\prime \prime} / 28^{\circ} 27^{\prime} 10^{\prime \prime}$ & 29 & 100.6 & 52.3 \\
\hline 22 & Castillo de Lara & $14^{\circ} 03{ }^{\prime} 24^{\prime \prime} / 28^{\circ} 24^{\prime} 41^{\prime \prime}$ & 470 & 190.4 & 45.1 \\
\hline 23 & Antigua-Agua de Bueyes & $14^{\circ} 01^{\prime} 25^{\prime \prime} / 28^{\circ} 22^{\prime} 46^{\prime \prime}$ & 280 & 150.9 & 43.7 \\
\hline
\end{tabular}


To ensure consistency and quality of the series, four tests of homogeneity were applied: the Standard Normal Homogeneity Test (SHNT) defined by Alexandersson (1986) and subsequently modified by Alexandersson and Moberg (1997), the Pettitt test (Pettitt, 1979), the Buishand rank test, and the Von Neumann test (Buishand, 1982). As stated in Cropper and Hanna (2014), the SHNT is more suitable for identifying inhomogeneities at the beginning and end of each set, while the Buishand and Pettitt tests are more sensitive to changes in the middle of the series. The significance level (1\%) for each homogeneity test was calculated using 10,000 Monte Carlo simulations (Wilks, 1995). On average, homogeneity tests were performed in monthly, seasonally and annual time series.

\section{Methods}

The precipitation concentration index (CI) was applied to determine the structure of precipitation at a daily scale and to evaluate the weight of the heaviest rainy episodes in the total precipitation (Cortesi et al., 2012; Martin Vide, 2004). To this end, humid days are grouped in series at intervals of $1.0 \mathrm{~mm}$. The rainfall totals and the number of days in each of the intervals were recorded.

The application of CI requires reliable data, especially in relation to the annotation of the smallest amounts of rainfall, that is, those of very low intensity with less than 1 $\mathrm{mm}$. Otherwise, the value of the CI might be considerably distorted, since this is based precisely on the distribution of absolute frequencies in classes of one millimeter. Thus, data cleansing was necessary. Those series that did not conform to a negative exponential distribution had to be rejected, because this mismatch was the result of an incorrect record of rainfalls below $1 \mathrm{~mm}$. This can be seen in Fig. 2 (A). On the other hand, in some series and for certain periods, values below $1 \mathrm{~mm}$ were not recorded properly due to changes in the measurement systems. For instance, in Fig. 2 (B) clear differences can be observed in those records below $1 \mathrm{~mm}$ before and after 1990 in Fuerteventura airport. Consequently, these series were also not considered (Fig. 2). For both reasons, only eleven series were taken into account.

The non-parametric Mann-Kendall test (Kendall, 1975; Mann 1945) was applied to determine the series with linear trends in seasonal and annual precipitation, as well as trends in CI series. This method has been used in numerous trends analyses in both climatology -applied to different variables such as temperature, precipitation, and even evapotranspiration processes (Hossein et al., 2011) - and other disciplines such as hydro-geography, where it has been used with datasets of river discharges, modifying the test to eliminate the effect of the test serial correlation (Yue and Wang, 2004).

The Mann-Kendall test has two useful features: (i) it is a nonparametric test that does not require normally distributed data, and (ii) it is not sensitive to the absence of data. The test establishes the null hypothesis that there is no linear trend in the series; that is, the data are independent and are randomly distributed. The alternative hypothesis assumes a tendency in the time series. 
Statistical significance can be set considering different p-values. In similar studies, $\mathrm{p}<0.10$ has been accepted, i.e., a significance of $90 \%$ and $\mathrm{Z}=1.645$ (Cortesi et al., 2012). In other cases, the significance required is up to $95 \%$ and $99 \%$ with $\mathrm{Z}=1.96$ and 2.575 , respectively (Cropper and Hanna, 2014). Given the strong variability of precipitation in the Canary Islands, in the present paper, the statistical significance was set to $30 \%$.
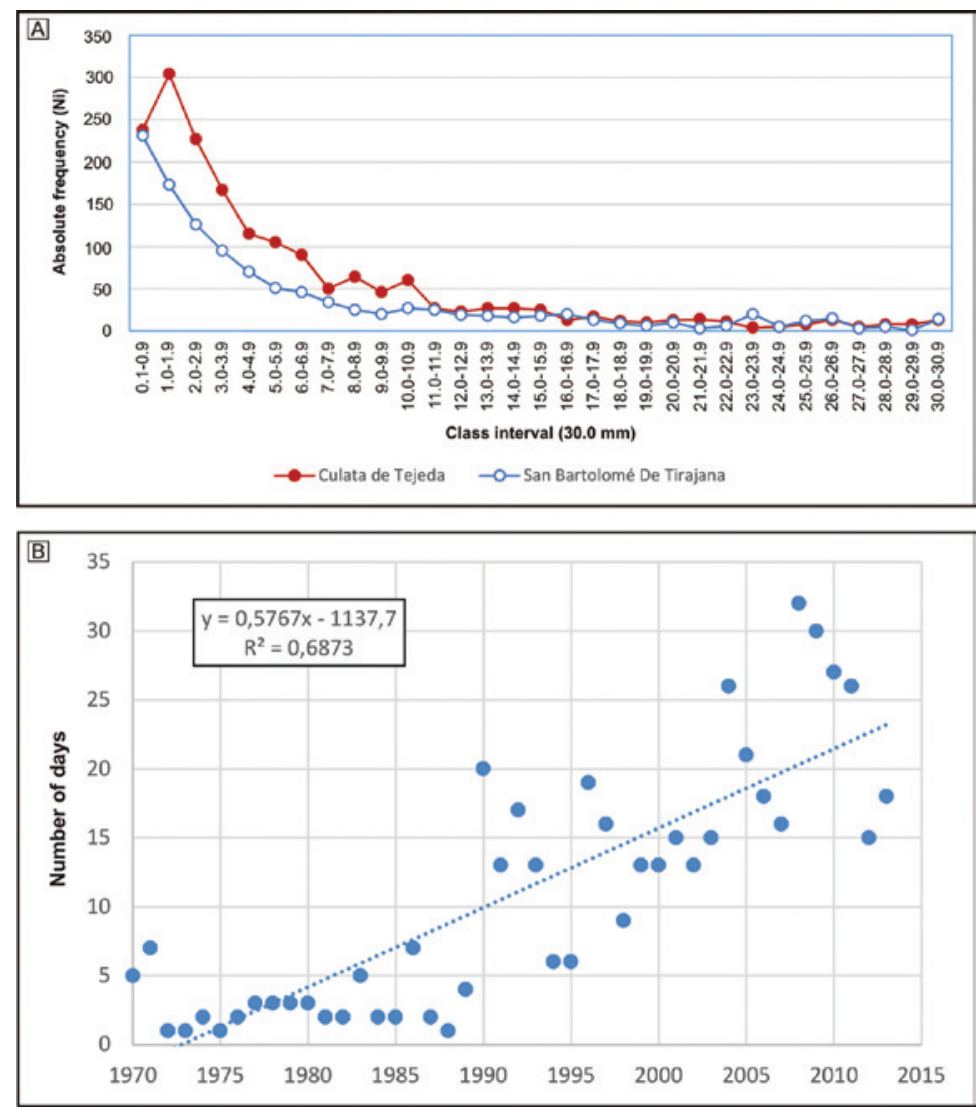

Figure 2. Absolute frequencies (in one-millimeter classes) of Culata de Tejeda and San Bartolomé de Tirajana (Gran Canaria) in the first 30 class intervals (A). Year-on-year variation in the number of days with rainfall below $1 \mathrm{~mm}$ in Fuerteventura airport (B).

\section{Results}

The results are reported in the following sequence: (i) the results of the homogeneity test applied to the different series; (ii) the analyses of annual and seasonal trends; and (iii) the results of the analysis of trends in the daily precipitation CI.

All analyzed series were homogeneous, except for five locations in summer (Gando Airport, San Juan de la Rambla, Yaiza, Teguise-Guatiza and Castillo de Lara). 
These locations were very insignificant because of the low rainfall recorded during summer months (between $0.1 \%$ and $4.3 \%$, depending on the altitude and orientation of the slopes), especially in the eastern islands. Deficiencies in data collection during the summer together with the scarce rainfall led to their exclusion from the trend analysis.

\subsection{Seasonal and annual trends in precipitation}

After the results of the Mann-Kendall test were analyzed, around 21\% of the series had a $\mathrm{p}<0.30$. Only one of them passed the test with a significance level of $95 \%$, and other three series passed at $90 \%$.

Of the three seasons of the year that we considered, spring was the one having a higher amount of significant trends. Fig. 3 (A) shows that this was the case for the localities at medium and high altitudes on the northern side of Gran Canaria (Tamaraceite, Lomo Majadilla, Valleseco and La Retamilla), where the trends were negative. In addition, the town of Cuevas Blancas, on the top of that island and with a northeastern orientation, had a significant negative trend with a significance level of $90 \%$. Haría, in the north of Lanzarote, also had a significant negative trend in this season. Most localities of the archipelago (i.e., $82 \%$ of the stations) presented a trend toward reduced rainfall, except some gauging stations located in the south and southwest of the islands (Los Llanos de Aridane, Vilaflor, Mogán and Tías), which had positive trends with significance levels of $30 \%$.

In contrast, as shown in Fig. 3 (B), most of the localities had positive trends in autumn. In the north, some series registered trends with a significance level of $30 \%$ (Arucas, Tamaraceite, Mayorazgo in Gran Canaria, and Haría in Lanzarote). A few stations showed negative trends, some of them located in areas of medium and high altitude (Vilaflor in Tenerife, La Culata de Tejeda and La Retamilla in Gran Canaria) and others located on east- and south-facing slopes in Lanzarote and Fuerteventura (Yaiza in Lanzarote and Fuerteventura airport).

Winter (Fig. 3 (C)) was dominated by negative trends in $70 \%$ of the series, particularly in the stations located on the northern slopes (except Presa de Jiménez in Gran Canaria). The other locations on the westernmost islands had positive trends (Los Llanos de Aridane in La Palma, Vilaflor in Tenerife, Gando and Mogán in Gran Canaria). The easternmost islands (Lanzarote and Fuerteventura) had primarily negative trends, except the stations of Haría and Teguise-Guatiza in Lanzarote. In six of the series the significance level was 30\% (San Juan de la Rambla and Vilaflor in Tenerife; Lomo Majadilla, Valleseco, Cuevas Blancas in Gran Canaria and Fuerteventura airport).

Finally, negative trends predominated in 15 of the 23 annual time series of precipitation (Fig. 4). Opposite trends were recorded in Presa de Jiménez, Arucas, Tamaraceite and Mayorazgo in the northern slopes of Gran Canaria, and Los Llanos de Aridane and Mogán in southwest of La Palma and Gran Canaria, respectively. In the easternmost islands, the trends were also negative, except Haría and Teguise-Guiatiza in Lanzarote. In three stations the test showed a $p<0.30$, all of them with negative trends. 

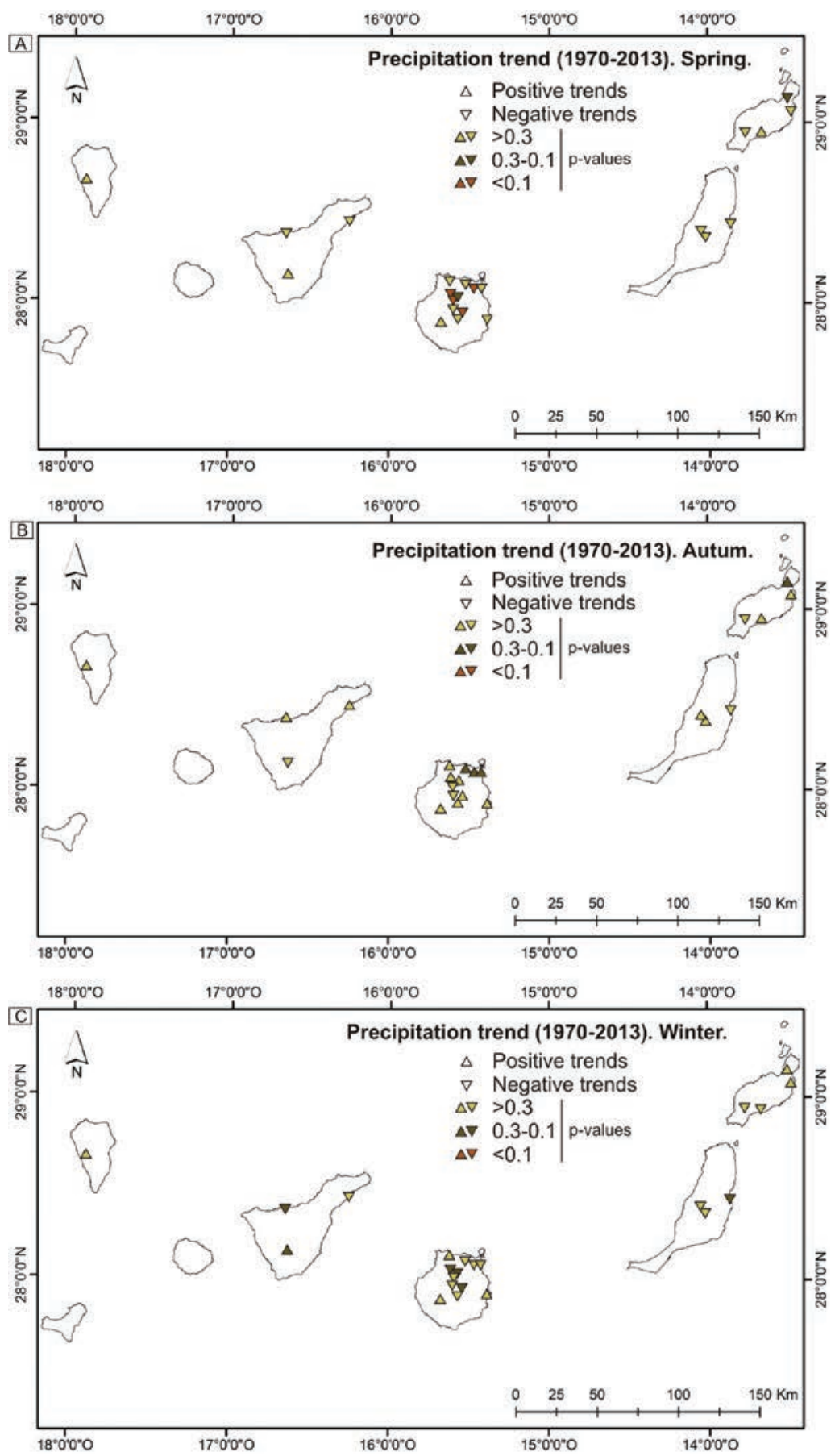

Figure 3. Trends of precipitation in the Canary Islands (1970-2013):

(A) spring, (B) autumn and (C) winter. 


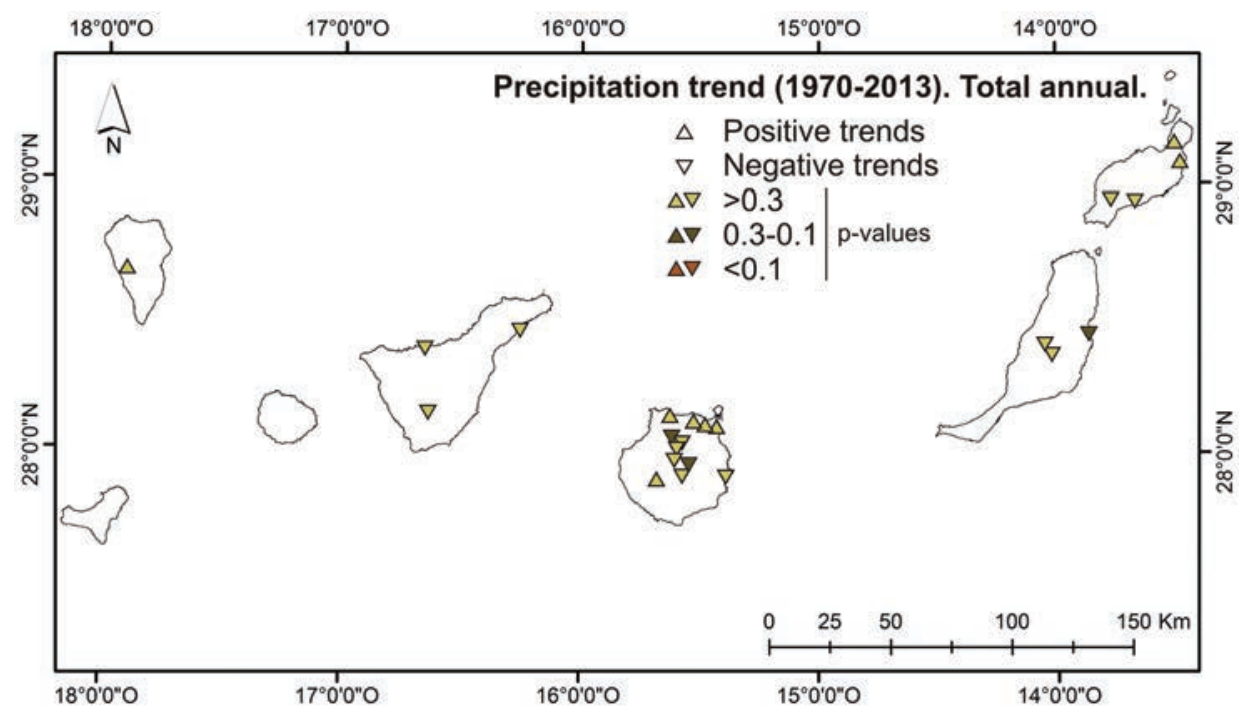

Figure 4. Annual precipitation trends in the 23 series considered (1970-2013).

In short, the trends were negative in most of the stations, except in autumn. In spring, $82 \%$ of the series had negative trends. This percentage was reduced to $70 \%$ in winter. Most of the stations on south- and southwest-facing slopes presented positive trends in both seasons. The increase of rainfall in autumn was registered in $78 \%$ of the stations, except in those with mostly south and southwest slopes. Annual precipitation also showed negative trends in $65 \%$ of the locations. All series with $\mathrm{p}<0.30$ recorded the negative seasonal and annual trend, except one weather station in winter.

\subsection{Trends in CI}

Daily CI values are presented in Table 2. CI values ranged between 0.634 and 0.725 , indicating that $73.74 \%$ and $82.83 \%$ of the annual precipitation was provided by the rainiest $25 \%$ days. Therefore, all CI values showed a high concentration in the distribution of daily rainfalls. As shown in Fig. 5, the lowest CI values were recorded in those locations where the rainfall was more regular throughout the year, generally, on the northern slopes of the islands. In any case, heavy rainfall events concentrated within a small number of days added large amounts of precipitation to the annual total records. It is not surprising, therefore, that the highest values of CI were similar to those of many towns in southern Europe, close to the Mediterranean Sea (Cortesi et al., 2012).

Regarding the analysis of CI trends, all stations showed positive trends toward greater concentrations of rainfall, except three stations (San Juan de la Rambla in Tenerife, San Bartolomé de Tirajana in Gran Canaria and Los Llanos de Aridane in La Palma). $73 \%$ had $\mathrm{p}<0.30$ and five of them showed $\mathrm{p}<0.05$. 
Table 2. Coefficients of a and $b$ for exponential curves, $C I$, coefficients of determination $\left(R^{2}\right)$ and percentage of precipitation contributed by $25 \%$ of the rainiest days for 11 rain gauge stations during the period 1970-2013 in the Canary Islands.

\begin{tabular}{clccccc}
\hline CD & Name & $\mathbf{a}$ & $\mathbf{b}$ & $\mathbf{C I}$ & $\mathbf{R}^{\mathbf{2}}$ & Rainfall (\%) \\
\hline 1 & Llanos de Aridane & 0.016 & 0.041 & 0.651 & 0.989 & 76.16 \\
2 & San Juan de la Rambla & 0.004 & 0.054 & 0.725 & 0.995 & 82.83 \\
3 & Santa Cruz de Tenerife & 0.007 & 0.048 & 0.722 & 0.977 & 81.39 \\
5 & Presa de Jiménez & 0.026 & 0.035 & 0.634 & 0.988 & 73.74 \\
6 & Arucas & 0.029 & 0.034 & 0.628 & 0.994 & 73.51 \\
7 & Tamaraceite & 0.023 & 0.036 & 0.647 & 0.989 & 74.82 \\
8 & Mayorazgo & 0.024 & 0.036 & 0.646 & 0.990 & 74.71 \\
14 & San Bartolomé de Tirajana & 0.015 & 0.040 & 0.680 & 0.994 & 78.24 \\
15 & Gando airport & 0.013 & 0.042 & 0.691 & 0.981 & 78.60 \\
16 & Barranquillo Andrés-Mogán & 0.016 & 0.040 & 0.658 & 0.996 & 76.47 \\
19 & Yaiza & 0.022 & 0.037 & 0.642 & 0.994 & 74.44 \\
\hline
\end{tabular}

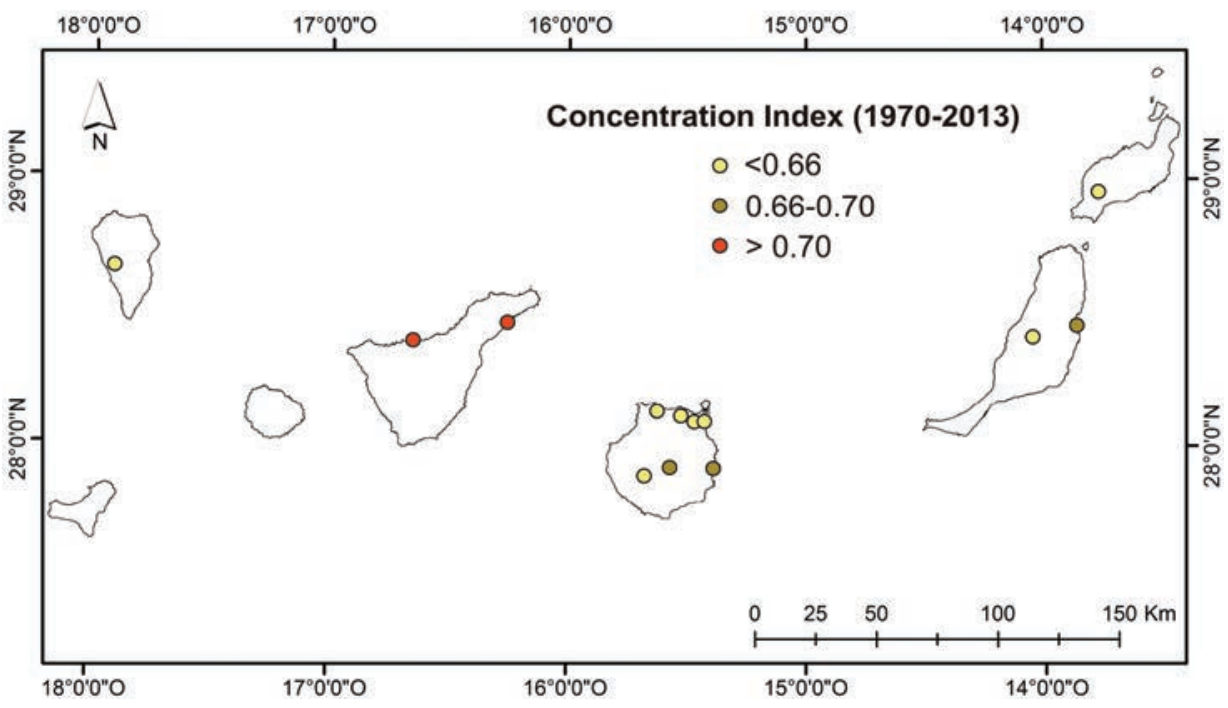

Figure 5. Annual values of CI at different stations of the Canary Islands.

\section{Discussion}

Despite the high number of rainfall stations in the Canary Islands, it is difficult to obtain series of precipitation with the basic requirements of continuity and reliability at daily scale. Nevertheless, there is a big difference between the eastern and western islands. In the first ones, different island and state agencies have historically monitored and controlled the data, while in the western islands, AEMET has managed the installation 
of rain gauges and controlled databases within fewer stations in relation to the surface of each island. The large spatial variability of precipitation in the Canary Islands requires a large number of observation points. Also, the lack of a good correlation between the series in some cases does not allow to get the missing data. However, we were able to select 23 series that meet the uniformity needed to carry out this study. Most of the series are located on the island of Gran Canaria due to the construction of dams during the 1950s which generated the need of adequately understand the rainfall behavior of the island. In this study we made distinct homogeneity tests with the monthly values of each of the series. In this regard, various stations of first order, such as those located at the airports, had to be rejected because the observed increase in CI values was a consequence of technological improvement in the measurements and not of a real change in the rainfall values.

The results are consistent with other studies that, with diverse methodologies, have shown decreases in annual rainfall over the northern slopes of the islands and insignificant changes over the southern slopes (Cropper and Hanna, 2014; García-Herrera et al., 2003; Luque and Martín Esquivel, 2011; Tarife et al., 2012), or a lack of significant trends in the majority of the stations because of the interannual variability of data (Sánchez-Benítez et al., 2016). The great variability of precipitation across the islands (with extremely rainy years interspersed with dry or very dry years) requires the use of very large datasets to obtain levels of significance similar to other regions where rainfall variability is lower.

In addition, events such that of March 31, 2002, in Santa Cruz de Tenerife, confirm the need for a long time series in the Canary Islands, and shows the relevant contribution of a single event to monthly and annual precipitation trends. That day, Santa Cruz de Tenerife recorded a rainfall of $233.0 \mathrm{~mm}$, multiplying the March average rainfall by 6.5 ; it also represented $92 \%$ of the rainfall in that month and $50 \%$ of the total rainfall for that year. Fig. 6 shows the effect of such episodes on the final time series trend for spring in Santa Cruz de Tenerife. Fig. 6 (b) has been modified by excluding the March 2002 data, resulting in a change in the trend of the series.
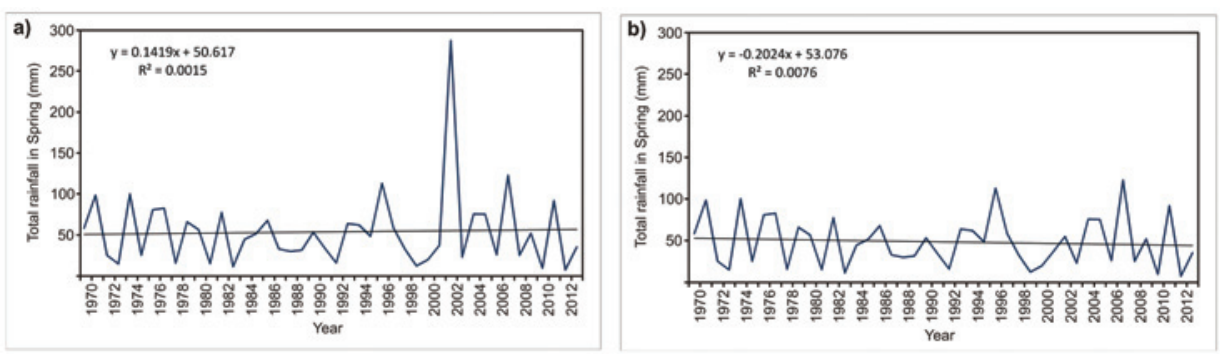

Figure 6. Changes in the spring precipitation trend in Santa Cruz de Tenerife (a) including the data from March 31, 2002, and (b) excluding this date.

\section{Conclusions}

One of the characteristics of rainfall in the Canary Islands is its pronounced annual irregularity, with very wet years followed by others that can be extremely dry. This 
marked variability of precipitation makes it difficult to obtain significant trends in both monthly/seasonal values and annual totals, especially over the eastern-, southern- and southwestern-facing slopes.

In addition, it is difficult to work with time series without temporal continuity, which is necessary for rigorous temporal analyses, particularly in the case of the western islands. Furthermore, many of the measuring stations have changed their location and/or measurement systems. There is, therefore, a need to homogenize the precipitation series and to consolidate metadata in order to more accurately detect changes in precipitation patterns. In this sense, the analysis should focus on the reconstruction of series as in the research carried out by Sánchez-Benítez et al. (2016).

This is the first time that the Mann-Kendall test has been applied to seasonal and annual precipitation and to CI values from the Canary Islands. The results varied according to the seasons and the different orientations of the slopes. Spring, which represented approximately $20 \%$ of the annual precipitation, exhibited negative trends in most of the analyzed time series $(82 \%)$. These negative trends were significant at some of the stations located in northern Gran Canaria. In contrast, the trend was positive in $78 \%$ of the series in autumn, season in which more than one-quarter of the annual rainfall occurred.

The winter was responsible for half of all annual rainfall in the Canary Islands. In this season, negative trends were observed at most of the stations (70\%). Given the importance of winter in the annual total, it is not surprising that the trends of the annual totals had the same sign than the trends observed in this season.

With respect to the values of $\mathrm{CI}$, changes in the measuring instruments forced us to reject numerous series. Nevertheless, it was possible to apply such index in eleven locations. The CI values were high in all cases, especially in Santa Cruz de Tenerife and San Juan de la Rambla. The trend toward a greater rainfall concentration was observed in most of series, generally with statistical significance. This trend suggests the increasing occurrence of severe rainfall events, such as the ones recorded in the last few years, with casualties (eight in the episode of March 31, 2002, in Tenerife) and negative consequences for economic activities, especially tourism.

Although this paper has confirmed the occurrence of trends in precipitation and CI values for some locations, it is necessary to go forward in the reconstruction of series with the purpose of obtaining more conclusive results.

\section{References}

Alexandersson, H. 1986. A homogeneity test applied to precipitation data. International Journal of Climatology 6, 661-675. http://doi.org/10.1002/joc.3370060607.

Alexandersson, H., Moberg, A. 1997. Homogenization of Swedish temperature data. Part I, homogeneity test for linear trends. International Journal of Climatology 17, 25-34. http:// doi.org/10.1002/(SICI)1097-0088(199701)17:1<25::AID-JOC103>3.0.CO;2-J.

Buishand, T.A. 1982. Some methods for testing the homogeneity of rainfall records. Journal of Hydrology 58, 11-27. http://doi.org/10.1016/0022-1694(82)90066-X 
Cortesi, N., González-Hidalgo, J.C., Brunetti, M., Martín-Vide, J. 2012. Daily precipitation concentration across Europe (1971-2010). Natural Hazards and Earth System Sciences 12, 2799-2810. http://doi.org/10.5194/nhess-12-2799-2012.

Cropper, T.E., Hanna, E. 2014. An Analysis of the climate of Macaronesia, 1865-2012. International Journal of Climatology 34, 604-622. http://doi.org/10.1002/joc.3710.

De Luque, A., Martín-Esquivel, J.L. 2011. Cualificación y homogenización de las series climáticas mensuales de precipitación de Canarias. Estimación de Tendencias de la Precipitación. Memoria Explicativa de Resultados. Agencia Canaria de Desarrollo Sostenible y Cambio Climático. Gobierno de Canarias, Santa Cruz de Tenerife.

García Herrera, R., Gallego Puyol, D., Hernández Martín, E., Gimeno Prresa, L., Ribera Rodríguez, P. 2001. Influence of the North Atlantic Oscillation on the precipitation in the Canary Islands. Journal of Climate 14, 3889-3993. http://doi.org/10.1175/1520-0442(2001)014<3889:IOTN $\mathrm{AO}>2.0 . \mathrm{Co} ; 2$.

García-Herrera, R, Gallego,D., Hernández,E., Gimeno,L., Ribera, P., Calvo, N. 2003. Precipitation trends in the Canary Islands. International Journal of Climatology 23, 235-241. http://doi. org/10.1002/joc. 870 .

Hossein, T., Safar, M., Aeini, A, Talaee, P.H., Mohammadi, K. 2011. Trend analysis of reference evapotranspiration in the western half of Iran. Agricultural and Forest Meteorology 151, 128-136. http://doi.org/10.1016/j.agrformet.2010.09.009.

Kendall, M.G. 1975. Rank correlation methods. Griffin, London.

Mann, H.B. 1945. Nonparametric tests against trend. Econometrica 13, 245-259. http://doi. org/10.2307/1907187.

Martin-Vide, J. 2004. Spatial distribution of a daily precipitation concentration index in Peninsular Spain. International Journal of Climatology 24, 959-971. http://doi.org/10.1002/joc.1030.

Marzol, M.V., Máyer, P. 2012. Algunas reflexiones acerca del clima de las Islas Canarias. Nimbus 29-30, 399-416.

Marzol, M.V., Yanes, A., Romero, C., Brito de Acevedo, E., Prada, S., Martins, A. 2006. Los riesgos de las lluvias torrenciales en las islas de la Macaronesia (Azores, Madeira, Canarias y Cabo Verde). In: Clima, Sociedad y Medio Ambiente. Actas del V Congreso de la Asociación Española de Climatología Serie A,5, Zaragoza, pp. 443-452.

Máyer, P. 2011. Lluvias e inundaciones en Gran Canaria, Islas Canarias, España. Editorial Académica Española, Madrid, 392 pp.

Pettitt, A. N. 1979. A nonparametric approach to the change-point problem. Applied statistics 28, 126-135. http://doi.org/10.2307/2346729.

Sánchez-Benítez, A., García-Herrera, R., Vicente-Serrano, S.M. 2016. Revisiting precipitation variability, trends and drivers in the Canary Islands. International Journal of Climatology. http://doi.org/10.1002/joc.4937.

Tarife, R., Hernández, S., Gámiz-Fortis, S.R., Castro-Díez, Y., Esteban-Parra, M.J. 2012. Análisis de los extremos pluviométricos en las islas Canarias y su relación con el índice NAO. En: Cambio climático, extremos e impactos. Actas del VIII Congreso de la Asociación Española de Climatología, Serie A, 8, Salamanca, pp. 659-668.

Wilks, D. 1995. Statistical Methods in the Atmospheric Sciences, an Introduction. Academic Press, San Diego.

Yue S, Wang C. 2004. The Mann-Kendall test modified by effective sample size to detect trend in serially correlated hydrological series. Water Resources Management 18, 201-218. http://doi. org/10.1023/B:WARM.0000043140.61082.60. 